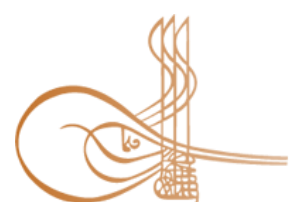

www.turkishstudies.net/language

\section{Turkish Studies - Language and Literature}

eISSN: 2667-5641

Research Article / Araștırma Makalesi

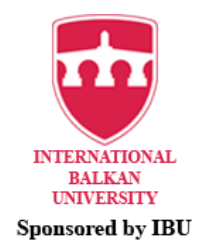

Sponsored by IBU

\title{
Yabancı Dil Olarak Türkçe Öğrenen Suriyeli Öğrencilerin Dinleme Becerisine Yönelik Kaygı Düzeylerinin İncelenmesi*
}

\author{
Study of Anxiety Levels for Listening Skills of Syrian Students Who Learn Turkish As A Foreign \\ Language
}

Bekir Sıttık Kılıç**

\begin{abstract}
The aim of this study is to identify the anxiety situations that arise during the process of developing the listening skills of Syrian students who learn Turkish as a foreign language. The "Listening Anxiety Scale" developed by Polat and Erişti (2018) has been used as a quantitative data collection tool in order to determine the levels of anxiety about listening ability of Syrian students who learn Turkish as a foreign language. Descriptive and predictive statistical techniques were used in the analysis of the quantitative data of this survey carried out in the screening model and the data were analyzed in SPSS 21 (Statistics Program for Social Sciences). In the qualitative dimension of the study, the semi-structured interview form developed by the researcher provided the students ' opinions on listening concerns and the data obtained after the interview were subject to content analysis. Kilis 7 Aralik University participated in the study in TÖMER (Turkish and foreign languages research and Application Center) the learning level B2 118 Turkish Syrian students. In obtaining qualitative data, 10 students were selected on a voluntary basis. The study found that gender characteristics of Syrian students who learned Turkish as a foreign language were a factor affecting listening anxiety; age, residential area of residence, etc. it concluded that variables are not a factor affecting listening anxiety. The lack of monitoring of listening, insufficient number of listening texts, the fast and poor sound quality of listening texts are among the reasons for listening concerns and some suggestions are listed based on these results.
\end{abstract}

Structured Abstract: Listening skill are the first to be acquired among other skills and form the basis for other skills, their use in daily life, educational activities is very important in mother tongue education and foreign language learning. Students who learn Turkish as a foreign language have to understand, interpret and express the sounds, new words and structures of the language that are not in their language. It can be thought that these factors that the student is not familiar with from birth in the process of being able to understand and react to what they are listening to are factors that may cause anxiety in the communication process (Altunkaya, 2017).

Anxiety, which means the feeling of tension (TDK, 2011), which is usually caused by the thought that something bad is going to happen, is a condition that has an effect on the educational processes. Anxiety from

* Bu çalışma 27-28 Haziran 2019 tarihinde 5. Uluslararası Yabancı Dil Olarak Türkçe Öğretimi Kongresi’nde sunulan bildirinin geliștirilmiș hâlidir.

*** Arş. Gör. Kilis 7 Aralık Üniversitesi, Muallim Rıfat Eğitim Fakültesi, Türkçe ve Sosyal Bilimler Eğitimi Bölümü

Res. Asst. Kilis 7 Aralik University, Muallim Rifat Faculty of Education, Department of Social Sciences and Turkish

Language Teaching

ORCID 0000-0003-3959-1867

bskilic@kilis.edu.tr

Cite as/ Atıf: Kılıç, B. S. (2020). Yabancı dil olarak Türkçe öğrenen Suriyeli öğrencilerin dinleme becerisine yönelik

kayg1 düzeylerinin incelenmesi. Turkish Studies - Language, 15(2), 947-962.

https://dx.doi.org/10.29228/TurkishStudies.40405

Received/Geliş: 02 January/Ocak 2020

Accepted/Kabul: 20 June/Haziran 2020

Copyright $\subset$ INTAC LTD, Turkey

Checked by plagiarism software

Published/Yayın: 27 June/Haziran 2020

CC BY-NC 4.0 
feelings about education as well as the language learning process can be seen as an important factor affecting the learning process. Foreign language anxiety is expressed as a marked confusion of personal perceptions, beliefs, feelings and behaviors related to language learning in the classroom, arising in the process of language learning (Horwitz, Horwitz and Cope; 1986). Listening skills are important in daily life, communication and education, so it is necessary to do studies on this subject (Tufekcioglu, 2014; Halat, 2015; Berber, 2016; Erdil, 2016; Altunkaya, 2017; Kadirim and Degec, 2017; Er, Bozkirli and Bicer, 2018; Kardas, Cetinkaya and Kaya, 2018; Polatcan, 2019 etc.).

The problems of teaching Turkish as a foreign language can be overcome by identifying the problems and finding solutions. In this study, it is aimed to determine the anxiety levels of the Syrian students who learn Turkish as a foreign language in the process of learning Turkish. In addition, different variables such as age, gender, settlement unit, type of settlement, duration of residence in Turkey were tried to determine the relationship between anxiety and anxiety. It is hoped that the study will help foreign students to be aware of the level of anxiety they feel in the process of learning the language, and that institutions that teach Turkish to foreign students, especially Syrian students, will be able to provide information about the listening anxiety they will experience while teaching Turkish to other foreign students, who in general learn Turkish as a foreign language. Using different methods and techniques in listening lessons, choosing different and rich content, repeating the issues that are not understood, providing opportunities for new learning, while making students feel positive about listening lessons; being dependent on the textbook, choosing long texts and technical problems, etc. it causes them to take a negative approach to listening lessons.

\section{Method}

The study used a mixed method in which quantitative and qualitative research methods were evaluated together. In the acquisition of quantitative data, The Listening Anxiety Scale (YDDKÖ) in foreign languages developed by Polat and Eristi (2018) was used, while in the collection of qualitative data, semi-structured interview developed by the researcher was used. The quantitative study group consists of 118 Syrian students in B2 level who continue their education at Kilis 7 Aralik University, Tömer. All statistical analyses were performed using SPSS 21 on the computer. In the study, T TEST and ANOVA test were used to determine the extent to which the students ' scores on the listening Anxiety Scale were evaluated by the independent variables. In the analysis of qualitative data, the data obtained from the participants as a result of face-to-face interviews are written. In order to master the data obtained, the written texts were read several times at different times and in the process, themes, categories and codes were made in parallel with the interview questions of the research. Content analysis was used in the analysis of the data as the raw data was analyzed without being separated into titles and new titles could be formed as a result of this analysis.

\section{Findings, Conclusions and Suggestions}

The study examined the listening concerns of Syrian students who learn Turkish as a foreign language in terms of some variables and it was determined that gender is a factor affecting listening anxiety; age, residence unit, residence location, residence time in Turkey are not factors affecting listening anxiety. In addition, there was no statistically significant difference between the listening activities of the students outside the course and the time spent on these activities. The inability to follow the eavesdropping, the insufficient number of eavesdropping, the fast and poor sound quality of the eavesdropping texts, the use of different mouths of Turks and the anxiety of listening to voice are among the reasons.

Keywords: language skills, listening anxiety, teaching Turkish to foreigners, Syrian students

Öz: Bu çalışmada amaç, Türkçeyi yabancı dil olarak öğrenen Suriyeli öğrencilerin dinleme becerilerini geliştirme sürecinde ortaya çıkan kaygı durumlarının belirlenmesidir. Yabancı dil olarak Türkçe öğrenen Suriyeli öğrencilerin dinleme becerisine yönelik kaygı düzeylerini tespit edebilmek amacıyla, nicel veri toplama aracı olarak Polat ve Erişti (2018) tarafindan geliştirilen "Yabancı Dilde Dinleme Kaygısı Ölçeği”" kullanılmıştır. Tarama modelinde yürütülen bu araştırmanın nicel verilerinin analizinde betimsel ve kestirimsel istatistik teknikleri kullanılmış veriler SPSS 21'de (Sosyal Bilimler için İstatistik Programı) analiz edilmiştir. Çalışmanın nitel boyutunda ise araştırmacı tarafından geliştirilen yarı yapılandırılmış görüşme formu ile öğrencilerin dinleme kaygıları ile ilgili görüşleri alınmış, görüşme sonrası elde edilen veriler içerik analizine tabi tutulmuştur. Çalışmanın örneklemini Kilis 7 Aralık Üniversitesi, TÖMER'de (Türkçe ve Yabancı Diller 
Uygulama ve Araştırma Merkezi) Türkçe öğrenen B2 kurundaki 118 Suriyeli öğrenci oluşturmaktadır. Nitel verilerin elde edilmesinde gönüllülük esasına bağlı kalarak seçilen 10 öğrenciden yararlanılmıştır. Çalışma ile Türkçeyi yabancı dil olarak öğrenen Suriyeli öğrencilerin cinsiyet özelliklerinin dinleme kaygısını etkileyen bir faktör olduğu; yaş, ikamet edilen yerleşim birimi gibi değişkenlerin dinleme kaygısını etkileyen bir faktör olmadığı sonucuna varılmıştır. Dinlenilenleri takip edememe, metinleri dinleme sayısını yetersiz görme, dinleme metinlerinin hızlı ve ses kalitelerinin kötü olma durumları, dinleme kaygılarının sebepleri arasında gördükleri tespit edilmiştir.

Anahtar Kelimeler: Dil becerileri, Dinleme kaygısı, Yabancılara Türkçe öğretimi, Suriyeli öğrenciler

\section{Giriş}

Dinleme becerisinin diğer becerilerden önce edinilmesi, diğer becerilere temel oluşturmas1, günlük hayatta, eğitim faaliyetlerinde çok kullanılması ana dil eğitiminde ve yabancı dil öğreniminde onu ön plana çıkarmaktadır. Yabancı dil olarak Türkçe öğrenim sürecinde öğrenciler, dillerinde olmayan sesleri, yeni kelimeleri, dile ait yapıları anlamak, yorumlamak ve ifade etmek durumunda kalmaktadır. Öğrencinin dinlediklerini anlayıp tepkide bulunabilme sürecinde doğuştan itibaren tanışık olmadığı bu etmenlerin iletişim sürecinde kaygı kaynağına sebep olabilecek etmenlerden olduğu düşünülebilir (Altunkaya, 2017). Yabancı dil kullanımı bir anlamda kişinin komik, garip kıyafetler giyip, sokağa çıkmasına benzemektedir (Ergür, 2004). Genelde yabancı bir dil öğrenmeyi özelde Türkçeyi yabancı bir dil olarak öğrenmeyi etkileyen birçok faktör bulunmaktadır. Bu faktörlerden biri de kaygıdır.

Ana dilinde farkında olmadan kazanılan bir beceri olmasına rağmen dinleme, herhangi bir dili yabancı veya ikinci dil olarak öğrenenler için yetkinlik kazanılmasında oldukça zorlanılan bir dil becerisi olarak karşımıza çıkmaktadır (Memiş, 2019). Dil becerilerinin birbirlerini etkiledikleri ve birbirlerinden etkilendikleri bilinmektedir. İnsanın günlük hayatta en fazla kullandığı beceri olan dinleme, diğer becerilerle doğrudan ilişki içindedir (Özaltun, 2018). Yabancı dil öğretiminde diğer becerilerin kazandırılmasında dinleme becerisinin eğitiminin önemli bir çerçevede ele alınması ve öğrenen konumundaki bireyin bilişsel, duyuşsal ve psikolojik dezavantajları ile birlikte düşünülmesi gerekmektedir (Yaman ve Tulumcu, 2016). Dolayısıyla dinleme becerisinin etkin kullanımı ana dilde temellenmekte yabancı dil öğrenme üzerinde etkili olabilmektedir. Öğrencinin hedef dilde dinleme becerisini geliştirebilmesi için, belirli dil bilgisel yapıları, bu yapılar aracıllğ̆ ile kültürel ayrıntıları tanıması gerekir (Durmuş, 2013 s. 142). Diller İçin Avrupa Ortak Öneriler Çerçevesi ${ }^{1}$ programında kur düzeyine göre dinleme becerisi kazanımları şu şekildedir:

\footnotetext{
${ }^{1}$ https://www.telc.net/fileadmin/user_upload/Publikationen/Diller_iain_Avrupa_Ortak_oneriler_AEeraevesi.pdf. Erişim tarihi[15.05.2019]
} 
Tablo 1: Diller İçin Avrupa Ortak Öneriler Çerçevesi Dinleme Becerisi Ortak Öneri Düzeyleri

\begin{tabular}{ll}
\hline Düzey & Ortak Öneri Düzeyleri Dinleme Yeterlikleri \\
\hline & $\begin{array}{l}\text { Benimle ya da ailemle ilgili veya benim çevremde dolaşan somut şeyleri } \\
\text { bildiğim sözcüklerle çok basit tümcelerle ve ancak yavaş yavaş ve tane tane } \\
\text { k1 }\end{array}$
\end{tabular}

A2

Tek tek tümceleri ve günlük yaşamda en çok kullanılan sözcükleri, eğer benim için, örneğin, kişi ve aile, alışveriş yapma, iş, yakın çevre üzerine ve benzeri gibi önemli şeylerle ilgili ise anlayabilirim. Kısa, açık ve basit mesajları ve duyuruları anlayabilirim.

Anlaşılır ve ölçünlü dil kullanıldığında ve iş, okul, boş zaman etkinlikleri ve benzeri gibi bilinen şeyler söz konusu olduğunda, konuşmanın ana noktasını

B1 anlayabilirim. Eğer oldukça yavaş ve açık konuşulursa güncel olaylar, benim mesleğim ve ilgi alanlarımla ilintili radyo ve televizyon yayınlarından temel bilgileri anlayabilirim.

B2

Bildiğim bir konuda uzun konuşma metinlerini ve sunumları, hatta işlenen konudaki karmaşı gerekçelendirmeleri anlayabilirim. Televizyonda çoğu haber yayınlarını ve güncel söyleşileri anlayabilirim. Ölçünlü dil konuşulduğunda çoğu filmi anlayabilirim.

$\mathrm{C} 1$

Uzun konuşmaları, açıkça yapılandırılmamış ve ilişkiler açıkça belirtilmemiş olsa bile takip edebilirim. Televizyon yayınlarını ve filmleri fazla zorluk çekmeden anlayabilirim.

İster canlı ister medyada konuşulan dili, hatta hızlı konuşulsa bile, anlamakta $\mathrm{C} 2$ hiçbir zorluk çekmem. Sadece farklı konuşma türüne/aksana alışabilmem için biraz zamana ihtiyacım olabilir.

Sözcükler ve basit cümlelerin anlaşılması ile başlayan dinleme etkinlikleri, kur derecesine bağlı olarak gittikçe zorlaşmakta ve yeni dil öğrenen bireylerde bazı kaygılara sebep olabilmektedir. Üzüntü, endişe duyulan düşünce, tasa; genellikle kötü bir şey olacakmış düşüncesiyle ortaya çıkan ve sebebi bilinmeyen gerginlik duygusu (TDK, 2011) anlamına gelen kayg1, eğitim süreçleri üzerinde etkili olan bir durumdur. Eğitimin yanı sıra dil öğrenim sürecine ilişkin duygulardan kaygı, öğrenme sürecini etkileyen önemli bir faktör olarak görülebilir. Yabancı dil kaygısı, dil öğrenme sürecinde ortaya çıkan, sınıfta dil öğrenmeyle ilgili kişisel algılar, inançlar, duygular ve davranışların belirgin bir karmaşası olarak ifade edilmektedir (Horwitz, Horwitz ve Cope; 1986). Dinleme kaygıs1, bireyin iletişim sürecinde dinlediklerini anlamlandıramama tehdidi altında kendisini huzursuz, gergin, endişeli hissetmesi ve bu hislere bağlı olarak kalp atım hızında değişiklik, kızarma, terleme gibi fiziksel tepkiler hissetmesidir (Altunkaya, 2017: s.109). Bu durumda hem dinleyene hem konuşana önemli roller düşmektedir. Konuşmacı, ileteceği mesajı dile getirirken hedef kitlenin özelliklerini göz önünde bulundurmalı, kelimeleri ona göre seçmeli, kuracağı cümlelerin uzunluğunu ona göre seçmeli, hedef kitlenin eğitim seviyesine dikkat etmelidir (Doğan, 2016: s.6). Çeşitli araştırma sonuçlarının yabancı dil öğrenim kaygısı, yabanc1 dil öğreniminde başarıyı etkileyen belirleyici bir unsur olduğunu ifade etmektedir (Taghreed akt. Tunçel, 2014). Dinleme becerisinin günlük hayatta, iletişimde, eğitimde ve dil öğrenme konusunda önem arz etmesi bu alanda çalışmalar yapılmasını gerekli kılmıştır.

Tüfekçioğlu (2014) Türkçenin yabancı dil olarak öğretiminde dinleme becerisi aracıllı̆̆ ile sözcük öğretimi yapılmasının, sözcük öğretiminde başarı sağladığını, dinleme becerisi kapsamında yapılan sözcük öğretiminin, öğrenicilerin Türkçe dil becerilerine önemli katkılar yaptığını tespit etmiştir. Halat (2015), yabanc1 dil olarak Türkçe öğrenen öğrencilerin dinleme becerisini kazanmaları sırasında yaşadıkları kaygının, düzeyini ve sebeplerini araştırdığı çalışmada kaygı 
sebeplerini, telaffuz, vurgu ve tonlama, konuşma hızı ve beden dili, dinleme sırasında bir bölümün kaçırılması durumunda bütünü anlayamama korkusu ve özgüven olmak üzere üç boyutta toplamıştır. Aynı çalışmada Türkçeyi yabancı dil olarak öğrenenlerin dinleme becerisine yönelik kaygıları ile katılımcıların cinsiyet ve yaş durumları arasında anlamlı bir farklılığa rastlanmamıştır. Berber (2016) yabancı dilde dinleme kaygısı ve yabancı dilde dinleme-anlama stratejileri arasındaki ilişkiyi incelemiş, yabancı dilde dinleme endişesi ile yabancı dilde dinleme-anlama strateji kullanımının birbirini etkilediğini ortaya çıkarmıştır. Erdil (2016) Türkçe öğrenen yabancı öğrencilerin, Türkçe öğrenme sürecinde yaşadıkları kaygı faktörünün, dil öğrenme üzerindeki etkisini incelediği çalışmada yabancı öğrencilerin, cinsiyeti, yaşı, geldikleri ülkeler, anadilleri ve anadili dışında bildikleri diğer dillerin sayıs1, Türkiye'ye gelme sebepleri gibi değişkelerin kaygı faktörü üzerinde istatistiksel olarak anlamlı bir farklılık olușturmadığını tespit etmiş ve yabancı öğrencilerin 'orta düzeyli' bir kaygıya sahip oldukları sonucuna ulaşmıştır. Altunkaya (2017) yabancı dil olarak Türkçe öğrenenlerin dinleme ve okuma kaygı düzeylerini tespit ederek, ikisi arasındaki ilişkiyi ve öğrencilerin okuma ve dinleme kaygılarını cinsiyet, yaş, ne kadar süredir Türkçe öğrendikleri ve Türkçe öğrenme amaçları değişkenlerine göre incelemiştir. Çalışmada öğrencilerin dinleme ve okuma kaygısı genel düzeylerinin orta seviyede olduğu, cinsiyet, yaş ve öğrencilerin Türkçe öğrenim süreleri değişkeni açısından kaygı düzeylerinde anlamlı bir farklılık bulunmadığı tespit edilmiştir. Kaldırım ve Degeç (2017) Türkçeyi yabancı dil olarak öğrenen üniversite öğrencilerinin karşılaştıkları dinleme sorunlarını tespit etmek için yaptıkları çalışmada katılımcıların, aksanlı konuşma, deyimler ve atasözlerinin kullanılması, anlamı bilinen sözcük varlığının yetersiz olması, konuşmacının ses tonunun yetersiz olması ve hızlı konuşması gibi durumlarda dinlediklerini anlamada zorlandıklarını tespit etmiştir. Er, Bozkırlı ve Biçer (2018) çalışmalarında Suriyelilere Türkçe öğretiminde dinleme becerisinin ihmal edilen bir beceri olduğunu ifade etmiş̧lerdir. Kardaş, Çetinkaya ve Kaya (2018) 2005-2017 yılları arasında dinleme/izleme beceri alanı ile ilgili çalışmaların eğilimlerini belirlemek amacıyla yaptıkları çalışmada eserlerde işlenen başlıca konuların; dinlemeye yönelik tutum, dinlediğini anlama, dinleme öğretimi, dinleme strateji/yöntem/teknikleri/türleri, dinleme etkinlikleri, dinleme sorunları, dinlemeye yönelik görüşler olduğunu tespit etmişlerdir. Yabancı dil olarak Türkçe öğretiminde kaygı üzerine yapılan araştırmaları inceleyen Polatcan (2019) yapılan araştırmaların çoğunlukla konuşma dil becerisiyle ilgili olduğunu, okuma ve dinleme dil becerilerinin sıklıkla araştırılmadığını tespit etmiştir. Araştırma sonuçlarına göre, kaygının yabancı dil öğrenme süreci üzerinde yararlı ve zararlı olmak üzere iki farklı yönde etkisi bulunmaktadır. Bir başka ifade ile yabancı dil kaygısı, çeşitli değişkenler dikkate alındığında dil öğrenmeyi bazen olumlu bazen de olumsuz bir biçimde etkilemektedir. (Aydın ve Zengin, 2008).

Türkçenin yabancı dil olarak öğretimi konusundaki problemlerin aşılması, sorunların belirlenmesi ve çözüm yollarının bulunması ile sağlanabilir. $\mathrm{Bu}$ da alanda yapılan bilimsel araştırmaların beklenen düzeyde olması ile sağlanabilmektedir. Bu çalışmada, Türkçe öğrenen Suriyeli öğrencilerin, Türkçe öğrenme sürecinde dinleme becerisine yönelik kaygı düzeylerinin belirlenmesi amaçlanmaktadır. Ayrıca yaş, cinsiyet, yerleşim birimi, yerleşim türü, Türkiye'de ikamet edilen süre gibi farklı değişkenlerin dinleme kaygısı ile ilişkisi belirlenmeye çalışılmıştır. Çalışmanın yabancılara Türkçe öğreten kurumların, özelde Suriyeli öğrencilere genelde Türkçeyi yabanc1 dil olarak öğrenen diğer yabancı öğrencilere Türkçe öğretirken yaşayacakları dinleme kaygısı hakkında bilgi verebileceği ayrıca Türkçe öğrenen yabancı öğrencilerin de dil öğrenme sürecinde hissettikleri kaygı düzeyinin farkında olmalarına yardımcı olacağı umulmaktadır. Çalışmanın bu anlamda alana katkı sağlayacağı düşünülmektedir. 


\section{Yöntem}

\section{Araştırmanın Deseni}

Çalışmada nicel ve nitel araştırma yöntemlerinin bir arada değerlendirildiği karma yöntem kullanılmıştır. Nicel verilerin elde edilmesinde Polat ve Erişti (2018) tarafından geliştirilen Yabancı Dilde Dinleme Kaygısı Ölçeği (YDDKÖ), nitel verilerin toplanmasında ise araştırmacı tarafından geliştirilen yarı yapılandırılmış görüşme formu kullanılmıştır.

\section{Çalışma Grubu}

Araştırmanın nicel boyutundaki çalışma grubunu Kilis 7 Aralık Üniversitesi TÖMER'de eğitimlerine devam eden, B2 kurundaki 118 Suriyeli öğrenci oluşturmaktadır. Tablo 2'de çalışma grubuna ilişkin tanıtıcı bilgilere yer verilmiştir:

Tablo 2: Çalışma grubuna ait demografik özellikler

\begin{tabular}{cccc}
\hline Özellik & Düzey & Frekans (f) & Yüzde(\%) \\
\hline \multirow{2}{*}{ Cinsiyet } & Erkek & 52 & 44 \\
& Bayan & 66 & 56 \\
& Toplam & 118 & 100 \\
\cline { 2 - 4 } Yaş & $18-22$ & 88 & 75 \\
& 22 üstü & 30 & 25 \\
& Toplam & 118 & 100 \\
\cline { 2 - 4 } Yerleşim Birimi & İl & 82 & 69 \\
& İlçe & 36 & 31 \\
Yerleşim Türü & Toplam & 118 & 100 \\
\cline { 2 - 4 } & Ev & 86 & 73 \\
& Konteyner & 32 & 27 \\
Türkiye'de İkamet Edilen Süre & Toplam & 118 & 100 \\
\cline { 2 - 4 } & 0-2 yıl & 25 & 21 \\
& 2 yıldan fazla & 93 & 19 \\
& Toplam & 118 & 100 \\
\hline
\end{tabular}

Çalışmanın nitel boyutundaki çalışma grubunu ise yine aynı kurumda eğitimlerine devam eden kolay ulaşılabilir durum örneklemesine uygun olarak seçilen Suriye uyruklu 5'i kız, 5'i erkek 10 öğrenci oluşturmaktadır.

\section{Veri Toplama Araçları}

\section{Yabancı Dilde Dinleme Kaygısı Ölçeği (YDDKÖ)}

Nicel verilerin toplanmasında yabancı dil öğrenen bireylerin yabancı dilde dinleme etkinlikleri sürecinde yaşadıkları kaygı düzeyini belirlemek için, geçerlik ve güvenirlik sınamaları yapılmış, Polat ve Erişti (2018) tarafından geliştirilen Yabancı Dilde Dinleme Kaygısı Ölçeği (YDDKÖ) kullanılmıştır. Bir ölçek geliştirme çalışması olan bu araştırmada, alanyazında sıklıkla önerilen ölçek geliştirme adımları izlenmiş, ölçeğin geçerlik ve güvenirlik düzeyleri; açımlayıcı faktör analizi ve ortaya çıkan faktör yapısının doğrulanması amacıyla gerçekleştirilen doğrulayıcı faktör analizi yoluyla test edilmiştir.

Araştırmanın verileri, bir devlet üniversitesinin yabancı diller yüksekokulunda, İngilizce hazırlık öğrenimi gören ve amaçlı örnekleme yöntemlerinden ölçüt örnekleme yöntemine göre seçilen 407 öğrenciden elde edilmiştir. Katılımcı öğrencilerin 300'ü $(\% 73,7)$ erkek, 107'si $(\% 26,3)$ kadındır. Yaş değişkenine göre, 17-29 yaş aralığındaki katılımcı sayısı 214 (\%52,6); 20-22 yaş aralığındaki katılımcı sayısı $158(\% 38,8), 23$ ve üzerinde bir yaşa sahip katılımcı sayısı ise 35 (\%8.6)'tir. Öğrencilerin 243'ü $(\% 59,7)$ A2 orta düzey, 164'ü ise $(\% 40,3)$ B1 ileri düzey kur sınıflarında İngilizce öğrenimi görmektedirler.

Alanyazın incelemesi sonucunda, dinleme kaygısına yol açtığı rapor edilen değişkenler kümeler halinde listelenmiş, öğrenci verileri, binişiklik gösterenler dışında, ilgili oldukları başlıklara 
göre alanyazına dayalı olarak oluşturulan kümelere yerleştirilmiş ve çalışmayı, taslak madde havuzunun oluşturulması süreci izlemiştir. Oluşturulan 51 maddelik taslak madde havuzu, kapsam geçerliği çalışması amacıyla İngilizce öğretmenliği alanında doktora eğitimi tamamlamış, alanda en az 10 yıllık mesleki deneyime sahip üç farklı İngilizce alan uzmanının görüşüne sunulmuştur. Uzmanlardan elde edilen geribildirimler doğrultusunda, 10 maddenin ölçek taslağından çıkarılmasıyla, 41 maddeden oluşan bir yapıya ulaşılmıştır. Bu yapı, pilot uygulama olarak yabancı diller yüksekokulunda İngilizce öğrenimi gören toplam 40 öğrenciye, ölçek maddelerini ifade edilişi yönüyle açıklığı ve anlaşılırlığını değerlendirmeleri amacıyla uygulanmıştır. Öğrenci geribildirimleri doğrultusunda, ölçekteki bazı maddeler ifade ediliş biçimi yönüyle güncellenmiş, taslak ölçek yapısı; İngilizce öğretmenliği alanından 5, rehberlik ve psikolojik danışma alanından 3, eğitim programları ve öğretim alanından 2, ölçme ve değerlendirme alanından 1 ve Türk dili ve edebiyatı alanından 1 uzman olmak üzere farklı üniversitelerde görev yapan 12 uzmana gönderilmiştir. Uzmanlardan konu hakkında elde edilen geribildirimlerle oluşan maddeler taslak ölçek formundan çıkarılmış, uzmanların \% 70 ve üzerinde bir oranda görüş birliğine vardıkları toplam 25 madde ile taslak ölçek formuna son biçimi verilmiştir. Ölçek maddelerin tamamı ifade edilişleri ve puanlanması yönüyle pozitif yüklüdür. AFA ve DFA çalışmalarından elde edilen sonuçların oldukça iyi düzeyde bir uyumu yansıtması, gerek bütüncül olarak gerekse de demografik değişkenler ve faktörler bağlamında gözlemlenen iç tutarlık katsayılarının yüksek değerlere sahip olmasından hareketle, geliştirilen ölçeğin, bireylerin yabancı dilde dinleme kaygısını belirleme amacıyla kullanılabilecek, özgün, geçerli ve güvenilir bir ölçme aracı olduğu ifade edilmektedir.

\section{Kişisel Bilgi Formu}

"Kişisel Bilgi Formu" ile araştırmanın bağımsız değişkenleri olan ve dinleme kaygısı ile ilgili olduğu düşünülen etmenlerle ilgili bilgilerin toplanması amaçlanmıştır. Bu formda öğrencilerin "cinsiyet", "yaş", "yerleşim birimi”, "yerleşim türü” ve "Türkiye'de ikamet edilen süre" ve "ders dışı dinleme faaliyetleri”"ni kapsayan sorular yer almıştır. Yerleşim birimi il merkezi ve ilçeler olmak üzere ikiye ayrılmakta, ilçede kalanlar çadırkentlerde ikamet etmektedir. Çadırkentlerde nüfusun tamamına yakını Suriyeli olduğu için Türkçeye maruz kalma, Türkçe dinleme faaliyetlerine katılma imkânı il merkezinde ikamet edenlere göre daha sınırlıdır. Bu durumun dinleme kaygısı etkisi üzerindeki etkisi araştırılmaya çalışılmıştır. Yerleşim türü konteyner kent ile ev (müstakil) olarak ayrılmış bu durum da yabancı öğrencilerinTürkçeye maruz kalma imkânlarını etkilemektedir. Ayrıca Türkiye'de belli bir süre yaşama ve ders dışı dinleme faaliyetlerine katılma durumlarıyla dinleme kaygısı arasında anlamlı bir fark olup olmadığı tespit etmek için sözkonusu değişkenler tercih edilmiştir.

\section{Görüşme}

Çalışmada nitel veri toplama aracı olarak görüşme tercih edilmiş̧ir. Görüşme insanların bir durum, konu hakkında ne düşündükleri, düşüncelerinin sebeplerini anlamak için yapılan sözlü iletişim türlerinden biridir. Görüşme yoluyla, deneyimler, tutumlar, düşünceler, niyetler ve yorumlar ve zihinsel algılar ve tepkiler gibi gözlenemeyeni anlamaya çalışılmaktadır (Yıldırım ve Şimşek, 2018: 130). Araştırmada Suriyeli öğrencilere 'yarı yapılandırılmış görüşme formu' uygulanarak Türkçe öğrenirken dinleme becerisine ilişkin görüşleri sorgulanmıştır. Bu bağlamda araştırmamızda nitel veriler, mülâkat formu verilerine dayalı olarak görüşme tekniği kullanılarak elde edilmiştir. Görüşme formu araştırmacı tarafindan hazırlanmış ve alan uzmanı iki öğretim üyesi (Doç. Dr. ve Dr. Öğr. Üyesi) tarafindan kapsam geçerliliği gözden geçirilmiş sorulardan oluşturulmuştur. Yarı yapılandırılmış form hazırlanırken önce ilgili alan yazın taranmış, araştırma soruları ve literatür ışığında araştırmacı tarafından görüşme formu için açık uçlu 6 soru ve 1., 4., 6. sorulara ait sondalardan oluşan yarı yapılandırılmış görüşme formu hazırlanmıştır. Hazırlanan form ile ilgili olarak bir alan uzmanının görüşleri alınmış, başka maddeyle benzer özellikler gösteren maddeler görüşme formundan çıkarılmıştır. Daha sonra soruların öğrenciler tarafından yeterince anlaşılıp 
anlaşılamayacağını sınamak için örneklem grubuyla benzer özellikler taşıyan 2 öğrenci üzerinde pilot bir uygulama yapılmıştır. Uygulama sonrasında elde edilen veriler, 1 maddenin yeniden düzeltilmesi gerektiği noktasında bir fikir oluşturmuş, düzeltilen 1 maddeyle birlikte 3 maddelik görüşme formuna son şekli verilmiştir. Görüşme yapmayı kabul eden öğrencilerle sessiz ve güven ortamına dayalı bir odada yaklaşık 20-25 dakika süren görüşmeler yapılarak görüşmeler ses kayıt cihazıyla kaydedilmiştir. Kaydedilen görüşmeler daha sonra bire bir yazılı hâle getirilmiş ve analiz edilmiştir.

\section{Verilerin Analizi}

Bütün istatistiksel analizler, bilgisayarda SPSS 21 kullanılarak yapılmıştır. Araştırmada öğrencilerin Yabancı Dilde Dinleme Kaygısı Ölçeğinden aldıkları puanlar ile bağımsız değişkenler arasında anlamlı farklılık olup olmadığını saptamak amacıyla T testi ve ANOVA kullanılmıştır.

Nitel verilerin analizinde katılımcilardan yüz yüze görüşme sonucunda elde edilen veriler yazılı hâle getirilmiştir. Elde edilen verilere hâkim olabilmek için yazılı metinler farklı zamanlarda birkaç kez okunmuş, ilerleyen süreçte araştırmanın görüşme sorularına paralel olarak tema, kategori ve kodlamalar yapılmıştır. Elde edilen ham veriler başlıklara ayrılmadan analiz edildiği, bu analiz sonucunda yeni başlıklar oluşabileceği için verilerin analizinde içerik analizi kullanılmıştır. Çalışmada kodlama güvenirliğini sağlamak için araştırmacılar tarafindan ayrı ayrı kodlamalar yapılmıştır. Kodlama sonucunda oluşturulan ortak kodlar ile ilgili daha detaylı açıklamalar yapmak için örnek ifadelere yer verilmiştir. Araştırmacıların yaptığ 1 kodlama süreci karşılaştırılarak verilerin güvenirliği hesaplanmıştır. Bu hesaplama için Miles ve Huberman'1n (1994) “Görüş Birliği / (Görüş Birliği + Görüş Ayrılığı) x 100” formülü kullanılmıştır. Araştırmacılar arasındaki güvenirlik bu formül ,81 bulunmuştur. Uyum yüzdesinin ,70 veya daha üstü olması güvenilirlik için önemli görüldüğünden (Miles ve Huberman, 1994) analizin güvenilir olduğu düşünülmektedir. Bulgular, tablolar şeklinde sunulmuş ve örnek katılımcı ifadelerine yer verilmiştir. Bulgular bölümünde tablolarda geçen isimler (Seçkin, Çiğdem, Aylin, Fatma, Burak, Ersin...) görüşme yapılan öğrencilere ait olmayıp, araştırmacı tarafından rastgele seçilen isimlerdir.

\section{Bulgular}

\section{Nicel Bulgular}

Cinsiyet değişkenine göre Türkçe öğrenen Suriyelilerin dinleme kaygıları arasında fark olup olmadığını anlamak amacıyla bağımsız örneklemler $t$ testi uygulanmıştır. Analiz sonuçları Tablo 3 'te gösterilmiştir.

Tablo 3: Katılımcıların Cinsiyet Değişkenine Göre Dinleme Kaygılarına Yönelik Tutumlarının TTesti Sonuçları

\begin{tabular}{lccccc}
\hline Cinsiyet & $\mathrm{N}$ & $\begin{array}{c}\text { Aritmetik } \\
\text { Ortalama }\end{array}$ & $\begin{array}{c}\text { Standart } \\
\text { Sapma }\end{array}$ & $\mathrm{t}$ & $\mathrm{p}$ \\
\hline Kadın & 67 & 60,8806 & 10,24033 & 3,511 &, 001 \\
Erkek & 51 & 54,0000 & 10,93801 & & \\
\hline
\end{tabular}

Türkçeyi yabancı dil olarak öğrenen Suriyeli öğrencilerin, cinsiyet durumlarının dinleme kaygısı üzerinde anlamlı bir etkisinin olup olmadığını ortaya koymak amacıyla yapılan ilişkisiz örneklemler için $t$ testinde, kadın öğrencilerin dinleme kaygısı puanı ortalamaları $\left(\overline{\mathrm{x}}_{\text {kadın }}=60,8806\right)$, erkek öğrencilerin puan ortalamaları $\left(\overline{\mathrm{x}}_{\text {erkek }}=54,0000\right)$ arasında anlamlı bir fark görülmüştür $\left[\mathrm{t}_{116}=3,511, \mathrm{p}<0.05\right]$. Bu durumda cinsiyetin Suriyeli öğrencilerin dinleme kaygısını etkileyen bir faktör olduğu söylenebilir. 
Tablo 4: Katılımcıların Yaş Değişkenine Göre Dinleme Kaygılarına Yönelik Tutumlarının T-Testi Sonuçları

\begin{tabular}{|c|c|c|c|c|c|}
\hline Yaş & $\mathrm{N}$ & Aritmetik Ortalama & $\begin{array}{l}\text { Standart } \\
\text { Sapma }\end{array}$ & $\mathrm{t}$ & $\mathrm{p}$ \\
\hline $18-22$ & 88 & 56,9432 & 10,95063 & $-1,635$ & , 105 \\
\hline 22 üstü & 30 & 60,7333 & 11,01702 & & \\
\hline
\end{tabular}

Türkçeyi yabancı dil olarak öğrenen Suriyeli öğrencilerin yaş durumlarının dinleme kaygısı üzerinde anlamlı bir etkisinin olup olmadığını ortaya koymak maksadıyla yapılan ilişkisiz örneklemler için $\mathrm{t}$ testinde 18-22 yaş aralığındaki öğrencilerin dinleme kaygı puanı ortalamaları $\left(\overline{\mathrm{X}}_{18-}\right.$ $\left.{ }_{22}=56,9432\right), 22$ yaş üstü öğrencilerin puan ortalamaları $\left(\bar{X}_{22 u ̈ s t u ̈}=60,7333\right)$ arasında anlamlı bir fark görülmemiştir [ $\left.\mathrm{t}_{116}=-1,635, \mathrm{p}>0.05\right]$. Bu durumda yaş değişkeninin Suriyeli öğrencilerin dinleme kaygısını etkileyen bir faktör olmadığı söylenebilir.

Tablo 5: Katılımcıların İkamet Edilen Yerleşim Birimi Değişkenine Göre Dinleme Kaygılarına Yönelik Tutumlarının T-Testi Sonuçları

\begin{tabular}{|c|c|c|c|c|c|}
\hline $\begin{array}{l}\text { İkamet edilen yerleşim } \\
\text { birimi }\end{array}$ & $\mathrm{N}$ & Aritmetik Ortalama & $\begin{array}{l}\text { Standart } \\
\text { Sapma }\end{array}$ & $\mathrm{t}$ & $\mathrm{p}$ \\
\hline$\overline{\text { İl }}$ & 82 & 57,2317 & 10,72472 & $-1,002$ & ,318 \\
\hline İlçe & 36 & 59,4444 & 11,75328 & & \\
\hline
\end{tabular}

Türkçeyi yabancı dil olarak öğrenen Suriyeli öğrencilerin ikamet ettikleri yerleşim birimlerinin dinleme kaygısı üzerinde anlamlı bir etkisinin olup olmadığını ortaya koymak amacıyla yapılan ilişkisiz örneklemler $\mathrm{t}$ testinde il merkezinde yaşayan öğrencilerinin dinleme kaygı puan ortalamaları $\left(\bar{X}_{\mathrm{il}}=57,2317\right)$, ilçede ikamet eden öğrencilerin puan ortalamaları $\left(\bar{X}_{\text {ilçe }}=59,4444\right)$ arasında anlamlı bir fark görülmemiştir [ $\left.\mathrm{t}_{116}=-1,002, \mathrm{p}>0.05\right]$. Bu durumda ikamet edilen yerleşim biriminin Suriyeli öğrencilerin dinleme kaygısını etkileyen bir faktör olmadığı söylenebilir.

Tablo 6: Katılımcıların İkamet Edilen Yerleşim Yeri Değişkenine Göre Dinleme Kaygılarına Yönelik Tutumlarının T-Testi Sonuçları

\begin{tabular}{lccccc}
\hline İkamet edilen yerleşim yeri & $\mathrm{N}$ & Aritmetik Ortalama & $\begin{array}{c}\text { Standart } \\
\text { Sapma }\end{array}$ & $\mathrm{t}$ & $\mathrm{p}$ \\
\hline $\mathrm{Ev}$ & 87 & 57,4023 & 11,08158 &,- 830 &, 408 \\
Kamp (Konteyner kent) & 31 & 59,3226 & 10,99814 & & \\
\hline
\end{tabular}

Türkçeyi yabancı dil olarak öğrenen Suriyeli öğrencilerin ikamet ettikleri yerleşim yerinin dinleme kaygısı üzerinde anlamlı bir etkisinin olup olmadığını ortaya koymak amacıyla yapılan ilişkisiz örneklemler $t$ testinde evde (kendi evlerinde) yaşayan öğrencilerinin dinleme kaygı puan ortalamaları $\left(\overline{\mathrm{X}}_{\mathrm{ev}}=57,4023\right)$, kampta (konteyner kent) yaşayan öğrencilerin puan ortalamaları $\left(\overline{\mathrm{X}}_{\text {kamp }}=59,3226\right)$ arasında anlamlı bir fark görülmemiştir [ $\left.\mathrm{t}_{116}=-, 830, \mathrm{p}>0.05\right]$. Bu durumda ikamet edilen yerleşim yerinin Suriyeli öğrencilerin dinleme kaygısını etkileyen bir faktör olmadığı söylenebilir. 
Tablo 7: Katılımcıların Türkiye’de İkamet Ettikleri Süre Değişkenine Göre Dinleme Kaygılarına Yönelik Tutumlarının T-Testi Sonuçları

\begin{tabular}{lccccc}
\hline $\begin{array}{c}\text { Türkiye'de İkamet edilen } \\
\text { süre }\end{array}$ & $\mathrm{N}$ & Aritmetik Ortalama & $\begin{array}{c}\text { Standart } \\
\text { Sapma }\end{array}$ & $\mathrm{t}$ & $\mathrm{p}$ \\
\hline $0-2$ yll & 17 & 59,1176 & 8,23015 &, 909 &, 365 \\
2 yıldan fazla & 101 & 56,5941 & 10,92170 & & \\
\hline
\end{tabular}

Türkçeyi yabancı dil olarak öğrenen Suriyeli öğrencilerin Türkiye'de ikamet ettikleri sürenin dinleme kaygısı üzerinde anlamlı bir etkisinin olup olmadığını ortaya koymak amacıyla yapılan ilişkisiz örneklemler $t$ testinde $0-2$ yıldır Türkiye'de yaşayan öğrencilerinin dinleme kaygı puan ortalamaları $\left(\overline{\mathrm{X}}_{0-2 \mathrm{y} \text { y1 }}=59,1176\right), 2$ yıldan fazla Türkiye'de yaşayan öğrencilerin puan ortalamaları $\left(\overline{\mathrm{X}}_{2}\right.$ yıldan fazla $=56,5941$ ) arasında anlamlı bir fark görülmemiştir [ $\left.\mathrm{t}_{116}=, 909, \mathrm{p}>0.05\right]$. Bu durumda Türkiye'de ikamet edilen sürenin Suriyeli öğrencilerin dinleme kaygısını etkileyen bir faktör olmadığı söylenebilir.

Tablo 8: Katılımcıların Kurs Dışı Dinleme Etkinlikleri Değişkenine Göre Dinleme Kaygılarına Yönelik Tutumlarının Anova Testi Sonuçları

\begin{tabular}{|c|c|c|c|c|c|c|c|c|c|}
\hline $\begin{array}{c}\text { Kurs dişı } \\
\text { dinleme } \\
\text { etkinlikleri }\end{array}$ & $\mathrm{N}$ & $\mathrm{X}$ & S.s. & Varyanslar & K.T. & $\mathrm{Sd}$. & K.O. & $\mathrm{F}$ & $\mathrm{p}$ \\
\hline Sosyal medya & 20 & 54,8947 & 9,74049 & Gruplar aras1 & 562,893 & 4 & 140,723 & & \\
\hline $\mathrm{TV}$ & 19 & 57,6000 & 9,91755 & Gruplar içi & 13711,082 & 113 & 121,337 & & \\
\hline Dizi/film & 57 & 57,4386 & 12,21389 & Toplam & 14273,975 & 117 & & 1,160 &, 332 \\
\hline Müzik & 15 & 61,6000 & 10,45945 & & & & & & \\
\hline Diğger & 7 & 62,8571 & 6,44020 & & & & & & \\
\hline
\end{tabular}

Suriyeli öğrencilerin kurs dışında yaptıkları dinleme etkinliklerinin, dinleme kaygısı üzerinde etkili olma durumlarını sınamak için yaptıkları etkinliklere göre oluşturulan etkinliklerin ortalamaları ilişkisiz örneklemler için tekyönlü varyans analizi ile karşılaştırılmış, analiz sonunda sosyal medya ile dinleme etkinlikleri ortalaması $\left(\bar{X}_{\text {sosyal medya }}=54,8947\right)$, televizyon üzerinden yapılan etkinliklerin ortalamas1 $\left(\overline{\mathrm{X}}_{\mathrm{TV}}=57,6000\right)$, dizi/film etkinlikleri ile yapılan etkinliklerin ortalamas1 $\left(\overline{\mathrm{X}}_{\text {dizi/film }}=57,4386\right)$, müzik dinleyerek yapılan etkinliklerin ortalaması $\left(\overline{\mathrm{X}}_{\text {müzik }}=61,6000\right)$ ve diğer $\left(\overline{\mathrm{X}}_{\text {diğer }}=62,8571\right)$ dinleme etkinlikleri ortalamalarının arasında istatistiksel olarak anlamlı bir fark gözlenmemiştir. $\left.\left[\mathrm{F}_{(5-112)}=1,160, \mathrm{p}>0,05\right)\right]$.

Tablo 9: Katılımcıların Kurs Dışı Dinleme Süreleri Değişkenine Göre Dinleme Kaygılarına Yönelik Tutumlarının Anova Testi Sonuçları

\begin{tabular}{lccccccccc}
\hline $\begin{array}{c}\text { Kurs dışı dinleme } \\
\text { etkinlikleri }\end{array}$ & $\mathrm{N}$ & $\mathrm{X}$ & $\mathrm{S} . \mathrm{s}$. & Varyanslar & $\mathrm{K} . \mathrm{T}$. & $\mathrm{Sd}$. & K.O. & $\mathrm{F}$ & $\mathrm{p}$ \\
\hline Günde 1 saatten az & 30 & 57,7333 & 12,74940 & Gruplar aras1 & 144,300 & 5 & 28,860 & & \\
Günde 1 saat & 44 & 57,3864 & 11,71009 & Gruplar içi & 14129,675 & 112 & 126,158 & & \\
Haftada 1 saat & 31 & 57,9032 & 7,01596 & Toplam & 14273,975 & & & \multirow{2}{*}{, 229} &, 949 \\
Ayda 1 saat & 3 & 63,3333 & 12,85820 & & & & & & \\
Hiç & 10 & 59,1000 & 7,73305 & & & & & & \\
\hline
\end{tabular}

Suriyeli öğrencilerin kurs dışında yaptıkları dinleme etkinliklerine ayırdıkları sürelerin, dinleme kaygısı üzerinde etkili olma durumlarını sınamak için yaptıkları etkinlik sürelerine göre oluşturulan süreler ortalamaları ilişkisiz örneklemler için tekyönlü varyans analizi ile karşılaştırılmış, analiz sonucunda dinleme etkinliklerine günde bir saatten daha az süre ayrılan ortalama $\left(\overline{\mathrm{X}}_{\text {günde }} 1\right.$ saatten $\left.{ }_{\mathrm{az}}=57,7333\right)$, günde bir saat ayr1lan süre ortalamas $1\left(\overline{\mathrm{X}}_{\text {günde } 1 \text { sat }}=57,3864\right)$, haftada bir saat olarak ayrılan süre ortalaması $\left(\overline{\mathrm{X}}_{\text {haftada } 1 \text { saat }}=57,9032\right)$, ayda bir saat olarak ayrılan süre ortalamas $\left(\overline{\mathrm{X}}_{\text {ayda }} 1\right.$ saat $=63,3333)$ ve kurs dışında dinleme etkinliğine hiç süre ayırmayanların $\left(\bar{X}_{\text {hị̧ }}=59,1000\right)$ 
ortalamalarının en az ikisi arasında istatistiksel olarak anlamlı fark gözlenmemiştir. $\left[\mathrm{F}_{(5-112)}=, 229\right.$ $\mathrm{p}>0,05)]$.

\section{Nitel Bulgular}

Tablo 10: Öğrencilerin Türkçe öğrenme sürecinde kaygılandıkları dil becerilerine ilişkin bulgular A1: Temel dil becerilerinden en çok kaygılandığınız beceri hangisidir? Bunun sebebi/sebepleri neler olabilir?

\begin{tabular}{ccc}
\hline Yer: Kilis 7 Aralık Üniversitesi & Kodlayarak Temalandırma & Temalar \\
\hline
\end{tabular}

ERSIN, FATMA: Dinlemeden çok korkuyorum. Dinlediğim şey neyden bahsediyor unutuyorum. Dinlemede sınavlarda başarısız oluyorum. Okumada konuşmada sıkıntı yaşamıyorum. Sadece dinlemede sıkıntı yaşıyorum.

YUSUF, DENIZ: En çok dinlemede kaygılanıyorum. Çünkü bazı dinlemelerde hızlı geçiyor. İki defa dinleme az geliyor.

SEÇKİN: Dinlemede kişisel olarak bir kişiyle konuşunca kaygilanmiyorum da televizyonda bilgisayarda dinleme olduğunda ses fazla iyi gelmiyor onun için sıkıntı yaşıyorum.

BURAK: Dinleme bana göre en zor. Çünkü Türkçede her kişi farklı söylüyor. Çok yerde farklı mesela ben Yozgat'ta çalıştım orada kalk yerine "kah" diyorlar, yok yerine "yoh" diyorlar. Bu farklı konuşmalardan dolayı dinlemede ve anlamada zorlanıyorum. Ayrica bazı insanları anliyorum bazı insanları anlamıyorum. Yani derslerde hocalarımın anlattıklarını dinlediğimde anlıyorum ama başkaları hızlı konuştuklarından zor oluyor.

ÇİĞDEM: TÖMER'e ilk girdiğimde konuşmadan korkuyordum. Çünkü biz konuşmaya alışkın değiliz. Şimdi hiç korkmuyorum. Korkmamın sebebi belki yanlış bir şey diyeceğimdendi. Bir yanlış yaparım arkadaşlarım benimle dalga geçer diye korkuyordum.

AYLIN, FURKAN: Konuşmadan korkuyorum. Mesela karşımızdaki kişi yanlış anlar diye korkuyorum. Belki yanlış telaffuz yaparım diye korkuyorum.

BEYZA: Yazma. Çünkü sesli harfler var yazmada çok karıştırıyorum.
Takip etme güçlüğü

Başarısızlık

Dinleme miktarı

$$
\text { Kaygl }
$$

Dinleme metninin hızı

Dinleme türü

Dinlemenin kaynağı

Ağız özellikleri

Dil kullanımı

Sesletim

Yanlış anlaşılma

Korku

Tablo 10'a göre öğrencilerin yarıdan fazlası (6) dinleme becerisinde, diğerleri de konuşma (3) ve yazma (1) becerilerinde kaygı hissettiklerini ifade etmektedir. Suriyeli öğrencilerin yaşadıkları dinleme kaygısının sebepleri arasında dinlenilenleri takip edememe, dinleme sayısının (2 defa) yetersiz görülmesi, dinleme metinlerinin hızlı ve ses kalitelerinin kötü olması, Türklerin farklı ağızları kullanmaları ve sesletim gelmektedir. 
Tablo 11: Öğrencilerin dinleme derslerinde yaşadıkları kaygı durumlarına ilişkin bulgular A2: Dinleme derslerinde etkinlikler yapilırken neler hissediyorsunuz?

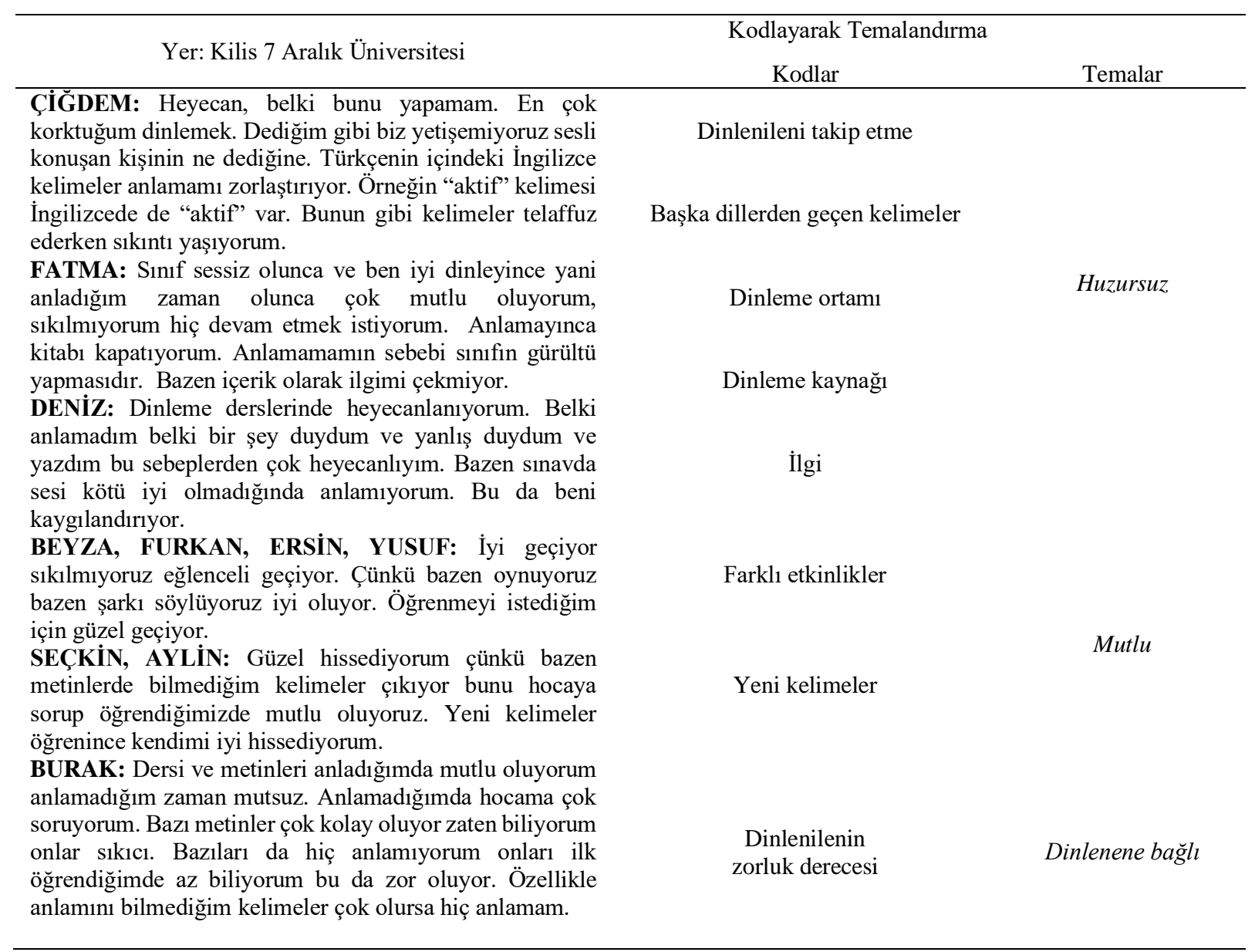

Öğrencilere dinleme derslerinde etkinlikler yapılırken neler hissettikleri sorulmuş ve alınan yanıtlardan hareketle Tablo 11 oluşturulmuştur. Tablo 11'e göre öğrencilerin yarısından çoğu derslerde farklı dinleme etkinlikleri yapılmasından, yeni kelime öğrenmelerinden dolayı kendilerini mutlu hissetmektedirler. Etkinlikler yapılırken dinlenileni takip etmekte, Türkçeye başka dilden geçen kelimeleri anlamakta güçlük çeken, dinleme ortamındaki gürültüden odaklanmada sorun yaşayan, dinleme içeriklerine ilgi duymayan öğrenciler etkinlikler esnasında kendilerini huzursuz hissetmektedirler. Bazı öğrenciler de durumu dinlenilen metnin güçlük derecesine bağlamaktadır. Eğer dinlenilen metin kolaysa ve anlaş1lıyorsa kendilerini mutlu değilse mutsuz hissetmektedirler. 
Tablo 12: Öğrencilerin dinleme dersi yöntem ve teknikleriyle ilgili görüşlerine ilişkin bulgular

A4: Derslerde yapılan dinleme yöntem ve teknikleri ile ilgili neler düşünüyorsunuz? Size göre seçilen dinleme yöntem ve teknikleri, dinleme derslerini nasıl etkiliyor?

\begin{tabular}{ccc}
\hline Yer: Kilis 7 Aralık Üniversitesi & \multicolumn{2}{c}{ Kodlayarak Temalandırma } \\
& Kodlar & Temalar \\
\hline
\end{tabular}

Çí̆gEM, AYLINN, DENiz, SEÇKİN: Derslerde biz zorluk yaşayınca hocam tekrar eder misiniz diye soruyoruz tekrar ediyor ve anlıyoruz. Metinler farklı farklı bizim için çok iyi. Bazen maç hakkında bazen tarih, moda bizim için önemli iyi farklı farklı şeyler görmemiz lazım.

BEYZA, YUSUF: Çeşitli metinler olduğu için çok iyi. Farklı konularda oluyor örneğin bir konu evlenme bir konu okumak ve bir sürü konu. Aynı konu olunca sıkılıyoruz. Dinlemede bazen hizlı oluyor anlayamiyoruz. Ama hoca tekrar yapıyor sonra anliyoruz.

FURKAN: Çok metin dinliyoruz. Şarkı, film, başka kitaplardan da dinliyoruz. Bazı konularda metinlerin içinde bilmediğimiz kelime çok olduğu için zorlanıyoruz. Fakat seçilen metinler genel olarak çok iyi.

FATMA: Bazı dinlemeler ya çok zor oluyor ya da çok kolay. Ortası yok. Zor olanlar konuları zor ve hızlı konuşuyorlar. Çok deyim kullanıldığı için anlamda problem yaşıyorum.

ERSIN: Hoparlörler bazen kötü ve sesi bazen normal değil. Tarihi eserler kültürler hakkında bilgiler alıyoruz. Metinler kolay ve normal.

BURAK: Bütün etkinlikler kitaptan yapılıyor. Bana göre bu etkinlikler faydalı değil. Bana göre dinleme metinlerinin tercümesi (yazlı olarak) kitapta olması lazım. Mesela internetteki dinleme etkinliklerinde aynı zamanda yazılı hâlleri var. Ama kitapta yok. Kitaptaki dinleme metinleri bir iki dakika. Bazı kelimeleri unutunca (kaçırınca) tüm dinleme kayboluyor, takip etmek zor oluyor.

Farklı ve zengin dinleme içerikleri

Tekrar

Olumlu

Yeni öğrenmeler

Zor içerik

Teknik problemler

Ders kitabına bağımlılık

Olumsuz

Dinlenilen metnin uzunluğu

Dinlenilen metnin yazılı hâlinin olmamas1

Öğrencilere dinleme derslerinde kullanılan yöntem ve teknikler hakkında düşünceleri sorulmuş ve onlardan gelen yanıtlardan hareketle Tablo 12 oluşturulmuştur. Derslerde farklı ve zengin içeriklerin seçilmesi (farklı konular), anlaşılmayan konuların tekrar edilmesi, yeni öğrenmelere imkân sağlaması öğrencilerin dinleme dersi yöntem ve teknikler hakkında olumlu görüş geliştirmelerine sebep olmaktadır. Derslerde kullanılan yöntem ve teknikler hakkında olumsuz bakış açısına sahip öğrenciler bunu derslerde zor ve uzun içeriklerin seçilmesine, hoparlör, ses sistemi gibi teknik sorunlara, ders kitabı haricinde farklı kaynaklar kullanılmamasına ve dinleme metinlerinin yazılı hâllerine yer verilmemesine bağlamaktadırlar.

\section{Sonuç ve Tartışma}

Çalışma ile Türkçeyi yabancı dil olarak öğrenen Suriyeli öğrencilerin dinleme kaygıları bazı değişkenler açısından incelenmiş ve cinsiyetin dinleme kaygısını etkileyen bir faktör olduğu; yaş, ikamet edilen yerleşim birimi, ikamet edilen yerleşim yeri, Türkiye'de ikamet edilen süre gibi değişkenlerin dinleme kaygısını etkileyen bir faktör olmadığı tespit edilmiştir, en etkili ilişkili değişkenin kurs dışı Türkçe dinleme faaliyetleri olduğu sonucuna varılmıştır. Ayrıca öğrencilerin kurs dışında yaptıkları dinleme etkinlikleri ve bu etkinliklere ayırdıkları süre ortalamaları arasında istatistiksel olarak anlamlı bir fark gözlenmemiştir. Çalışmanın bu sonucu yabancı dil olarak Türkçe öğrenenlerin cinsiyet ve yaşlarının kaygıyla ilişkili olmadığını gösteren daha önceki çalışmalarla cinsiyet değişkeni yönüyle farklı ve yaş değişkeni yönüyle benzer özellikler göstermektedir (Altunkaya, 2017; Erdil, 2016; Halat, 2015; Şen ve Boylu, 2015). 
Dinlenilenleri takip edememe, metinleri dinleme sayısının yetersiz görme, dinleme metinlerinin hızlı ve ses kalitelerinin kötü olması, Türklerin farklı ağızları kullanmaları ve sesletim dinleme kaygısının sebepleri arasında görülmektedir. Büyükikiz (2014) çalışmasında sınıf dışında standart Türkçenin kullanılmamasının (şive-ăğı kullanılması) dinlemeyi zorlaştırdığını tespit etmiştir. Çalışmanın bu sonucu daha önce yapılan çalışmayla benzerlik göstermektedir. Dinleme etkinlikleri sırasında dinlenileni takip etmede, Türkçeye başka dilden geçen kelimeleri anlamada güçlük çeken, dinleme ortamındaki gürültüden odaklanmada sorun yaşayan, dinleme içeriklere ilgi duymayan öğrenciler kaygı hissetmektedirler. Kaldırım ve Degeç (2017) çalışmalarında Türkçeyi yabancı dil olarak öğrenmekte olan üniversite öğrencilerinin deyimler ve atasözlerinin kullanıldığ 1 ve bilinmeyen kelimelerin sıkça geçtiği konuşmaları dinlerken anlamakta güçlük çektiklerini tespit etmiştir. Bu yönüyle araştırmanın sonuçlarının alan yazındaki diğer araştırmalarla örtüştüğü görülmektedir.

Dinleme derslerinde farklı yöntem ve tekniklerin kullanılması, farklı ve zengin içeriklerin seçilmesi, anlaşılmayan konuların tekrar edilmesi, yeni öğrenmelere imkân sağlaması öğrencilerin dinleme derslerine karşı olumlu yaklaşmalarını sağlarken; ders kitabına bağımlı kalınması, uzun metinler seçilmesi ve teknik sorunlar $v b$. dinleme derslerine karşı olumsuz yaklaşmalarına neden olmaktadir.

Sonuç olarak, Türkçeyi yabancı dil olarak öğrenen Suriyeli öğrenciler üzerinden yürütülen çalışmada cinsiyetin dinleme kaygısını etkileyen bir etken olduğu, yaş, ikamet edilen yerleşim birimi, ikamet edilen yerleşim yeri, Türkiye'de ikamet edilen süre gibi değişkenlerin dinleme kaygısını etkileyen bir faktör olmadığı, Suriyeli öğrencilerin kurs dışında yaptıkları dinleme etkinlikleri ve bu etkinliklere ayrılan süre ortalamaları arasında istatistiksel olarak anlamlı bir fark olmadığ tespit edilmiştir.

Suriyeli öğrenciler, dinleme becerisinde kaygı hissettmekte, dinlenilenleri takip edememe, metinleri dinleme sayısını yetersiz bulma, dinleme metinlerinin hılı ve ses kalitelerinin kötü olması, Türklerin farklı ağızları kullanmaları ve sesletim, dinleme kaygısına sebep olan durumlar arasında görmektedirler. Dinleme derslerinde farklı yöntem ve tekniklerin kullanılması dinleme becerisine karşı olumlu bakış kazandırdığı söylenebilir.

\section{Öneriler}

- Farklı cinsiyetteki, farklı ilgi ve ihtiyaçları olan öğrencileri için derslerde farklı dinleme metinleri kullanılmalı.

- Dinleme faaliyetleri derslerle sınırlandırılmamalı öğrencilere kurs dışında tamamlayıcı görevler verilmeli ve öğrenciler takip edilmelidir.

- Dinleme materyallerinin kalitesine ve hızına dikkat edilmeli, gerekirse dinleme süresi kurlara bağlı olarak artırılmalıdır.

\section{Kaynakça}

Altunkaya, H. (2017). Yabancı dil olarak Türkçe öğrenenlerin dinleme ve okuma kaygıları. Education Sciences (NWSAES), 12(3), 107-121.

Aydın, S. ve Zengin, B. (2008). Yabancı dil öğreniminde kaygı: bir literatür özeti. Dil ve Dilbilimi Çalışmaları Dergisi, 4(1), 0-94

Berber, G. (2016). Yabancı dilde dinleme kaygı seviyesi yüksek ve düşük öğrencilerin yabancı dilde dinleme-anlama strateji kullanımı. (Yayımlanmamış yüksek lisans tezi). Anadolu Üniversitesi, Eğitim Bilimleri Enstitüsü). 
Büyükikiz, K. K. (2014). Türkçeyi yabancı dil olarak öğrenen c1 düzeyindeki öğrencilerin dinleme becerisine ilişkin görüşleri. Gaziantep University Journal of Social Sciences, 13(3):793-805.

Doğan, Y. (2016). Dinleme eğitimi (4. baskı). Pegem Akademi Yayınları

Durmuş, M. (2013). Yabancılara Türkçe öğretimi (2. baskı). Grafiker Yayınları

Er, O., Bozkırlı, K. Ç. ve Biçer, N. (2018). Suriyelilere Türkçe Öğreten Öğretmenlerin Dinleme Becerisine Bakış Açılarının Değerlendirilmesi. International Online Journal of Educational Sciences, 10(3), 188-203.

Ergür, D. O. (2004). Yabancı dil öğrenimi sürecinde kaygı. Hacettepe Üniversitesi Eğitim Fakültesi Dergisi, 26(26), 48-53.

Erdil, M. (2016). TÖMER' de Türkçe öğrenen yabancı öğrencilerin Türkçe öğrenmeye ilişkin kaygı düzeyleri. Yayımlanmamış Yüksek Lisans Tezi, Çanakkale Onsekiz Mart Üniversitesi Eğitim Bilimleri Enstitüsü.

Göçer, A. (2009). Türkiye'de Türkçeyi yabancı dil olarak öğrenen lise öğrencilerinin hedef dile karş1 tutumlarının bazı değişkenler açısından incelenmesi. Electronic Turkish Studies, 4(8), 12981313. https://doi.org/10.7827/TurkishStudies.1001

Halat, S. (2015). Yabancl dil olarak Türkçe öğrenenlerin dinleme becerisine yönelik kaygı düzeylerinin incelenmesi. Yayımlanmamış Yüksek Lisans Tezi, Gazi Üniversitesi Eğitim Bilimleri Enstitüsü.

Horwitz, E.K., Horwitz, M.B., and Cope, J., (1986). Foreign Language Classroom Anxiety. The Modern Language Journal, Number:70, pp:125-132.

Kaldırım, A., ve Degeç, H. (2017). Türkçeyi yabancı dil olarak öğrenen öğrencilerin dinleme esnasında karşılaştıkları sorunlar. Eğitim Bilimleri Araştırmaları Dergisi, 7(1), 19-36.

Kardaş, M. N., Çetinkaya, V. ve Kaya, M. (2018). 2005-2017 yılları arasında dinleme eğitimi üzerine yapılmış akademik çalışmaların eğilimleri üzerine bir araştırma. Kuram ve Uygulamada Sosyal Bilimler Dergisi, 2(1), 21-32.

Memiş, M. R. (2019). Türkçe öğrenenlerin dinleme başarısını artırmak için kullanılabilecek iki farklı uygulama. Ondokuz Mayıs Üniversitesi Eğitim Fakültesi Dergisi, 38(2), 107-120.

Miles, M. B. \& Huberman, M. A. (1994). Qualitative data analysis. Sage Publication.

Özaltun, H. (2018). Yabancılara Türkçe öğretiminde sesli metinlerin dinlenebilirlik açısından tanımlanması ve sınıflandırılması. (Yayımlanmamış doktora tezi). İnönü Üniversitesi Eğitim Bilimleri Enstitüsü, Türkçe ve Sosyal Bilimler Eğitimi Ana Bilim Dalı Türkçe Eğitimi Bilim Dal1).

Polat, M. ve Erişti, B. (2018). Yabancı dilde dinleme kaygısı ölçeğinin geliştirilmesi. Electronic Turkish Studies, 13(11), 1113-1138. http://dx.doi.org/10.7827/TurkishStudies.13438

Polatcan, F. (2019). Yabancı dil olarak Türkçe öğretiminde kaygı üzerine yapılan araştırmaların incelenmesi. Ana Dili Eğitimi Dergisi, 7(1), 205-216.

Şen, Ü. ve Boylu, E. (2015). Türkçeyi yabancı dil olarak öğrenen İranlı öğrencilerin konuşma kaygılarının değerlendirilmesi. Mustafa Kemal Üniversitesi Sosyal Bilimler Enstitüsü Dergisi, 12(30), 13-25.

TDK (2011). Türkçe Sözlük (11. Basım). Türk Dil Kurumu Yayınları 
Tunçel, H. (2014). Yabancı dil olarak Türkçe öğrenimine yönelik kaygı ve kaygının dil öğrenimi başarısına etkisi. (Yayımlanmamış doktora tezi). Çanakkale 18 Mart Üniversitesi Eğitim Bilimleri Enstitüsü Türkçe Eğitimi Ana Bilim Dalı.

Tüfekçioğlu, B. (2014). Yabancı Dil Olarak Türkçe Öğretiminde Dinleme Etkinlikleri İle Sözcük Öğretimi Üzerine Bir Araştırma Çukurova TÖMER Örneği. E-Dil Dergisi, (2), 35-51.

Yaman, H. ve Tulumcu, F. M. (2016). Yabancı Dil Olarak Türkçe Öğrenenler İçin Dinleme Becerisi Öz Yeterlik Ölçeği Geliştirilmesi. Journal of Turkish Studies, 11(3), 2371-2386. http://dx.doi.org/10.7827/TurkishStudies.9327

Yıldırım, A., ve Şimşek, H. (2018). Sosyal bilimlerde nitel araştırma yöntemleri.(11. Baskı) Seçkin Yayınevi. 